\title{
Mono-allelic expression of the IGF-I receptor does not affect IGF responses in human fibroblasts
}

\author{
Elke Hammer ${ }^{1}$, Kerstin Kutsche ${ }^{2}$, Friedrich Haag ${ }^{3}$, Kurt Ullrich ${ }^{1}$, Ralf Sudbrak ${ }^{4}$, Rolf Peter Willig ${ }^{1}$, \\ Thomas Braulke $^{1}$ and Bernd Kübler ${ }^{1}$ \\ ${ }^{1}$ Children's Hospital, ${ }^{2}$ Institute of Human Genetics and ${ }^{3}$ Institute of Immunology, University of Hamburg 20246 Hamburg, Germany and \\ ${ }^{4}$ Max-Planck Institute for Molecular Genetics, 14195 Berlin, Germany \\ (Correspondence should be addressed to T Braulke; Email: braulke@uke.uni-hamburg.de)
}

\begin{abstract}
Objective: It has been suggested that mono-allelic deletion of the IGF-I receptor gene is causally related to severe intrauterine and postnatal growth deficiency whereas no IGF-I resistance was observed in the patients' fibroblasts. The expression and regulation of the growth-modulating IGF binding proteins (IGFBPs) have been investigated in serum and fibroblasts of a short girl with mono-allelic loss of the distal long arm of chromosome 15 (15q26.1-qter).

Patient and methods: The mono-allelic loss of the IGF-I receptor (IGF1R) gene was confirmed in a child with prenatal and severe postnatal growth retardation by fluorescence in situ hybridization, and was evaluated on the protein level in fibroblasts of the patient by FACS analysis and IGF cross-linkage. Additionally, expression of IGFBPs and cell-mediated degradation of IGFBP-3 were examined in the patient's fibroblasts.

Results: Levels of GH, IGF-I, and IGFBP-3 were above the 95th percentile in the serum of the 3-yearold girl with a mono-allelic deletion of the IGF1R gene, suggesting IGF-I resistance. In the patient's fibroblasts the IGF-I receptor concentration was half that in control cells. Whereas the pattern of secreted IGFBPs in response to IGFs was not altered, the abundance of secreted IGFBPs was higher in the patient's cells than in controls. Moreover, fibroblast-mediated degradation of ${ }^{125}$ I-labeled IGFBP-3 appears to be reduced in the patient's fibroblasts. The higher abundance of IGFBPs in the patient's fibroblasts might be responsible for the lack of IGF-I-stimulated $\left[\alpha-1-{ }^{14} \mathrm{C}\right]$ methylaminoisobutyric acid transport.

Conclusion: Our results suggest that the expression and regulation of IGFBPs in tissues from patients with mono-allelic deletion of the IGF-I receptor gene may lead to IGF sequestration and contribute to IGF-I resistance and growth retardation.
\end{abstract}

European Journal of Endocrinology 151 521-529

\section{Introduction}

Short stature is a very heterogenous condition controlled by multiple interplaying gene products. Growth disorders with a genetic origin can be either associated with chromosomal aberrations or caused by a single gene defect (1). One consideration, obviously, is a defect in the growth hormone-insulin-like growth factor I (GH-IGF-I) axis. GH stimulates the hepatic production of IGF-I affecting the serum IGF-I concentration that correlates in humans with somatic growth. In addition, GH acts directly on peripheral tissues and induces non-hepatic IGF-I synthesis for autocrine/paracrine actions (2). IGF-I, and to a lesser extent IGF-II, stimulate the proliferation, differentiation and survival of cells and exert metabolic effects which are preferentially mediated by the IGF-I receptor (3). This receptor belongs to the tyrosine kinase class of cell surface receptors and consists of two subunits forming an $\alpha_{2} \beta_{2}$ heterotetramer with structural and functional similarities to the insulin receptor (4). The $\alpha$ and $\beta$ subunits are encoded by a single gene, IGF1R, located on the distal long arm of chromosome 15 (15q26.3). The interaction of IGFs with the IGF-I receptor and the cellular response to IGFs are modulated by a family of six high affinity IGF binding proteins (IGFBP-1 to -6). In plasma, the IGFBPs function as transport proteins for IGFs, prolonging their half-lives and regulating their metabolic clearance (3). The cell- and tissue-specific expression pattern of IGFBPs can be regulated at the level of transcription which can be affected by various cytokines and hormones, as well as by post-translational modifications such as limited proteolysis. Proteolysis of IGFBPs by IGFBP-specific proteases is believed to be the major mechanism for the release of IGFs from IGFBP/IGF complexes, generating IGFBP fragments with reduced affinity for IGFs (5). Moreover, recent data suggest that IGFBPs and their proteolytic fragments not only modulate IGF actions, but also exert intrinsic IGF- and IGF-I receptor-independent bioactivities (6). 
The critical roles of IGFs and IGF-I receptor for preand postnatal growth as well as maintenance of various tissues have been demonstrated in several studies using gene-targeted mice (7-9). Similarly, patients with mutations in the IGF-I and IGF-I receptor gene show intrauterine growth retardation and severe 3 postnatal growth failure $(10,11)$. In addition, there are a few reports of patients with loss of one copy of IGF1R due to the deletion of the distal long arm of chromosome 15. These patients showed intrauterine and postnatal growth failure in addition to craniofacial and skeletal abnormalities, and mild to severe mental retardation. It has been suggested that hemizygosity for IGF1R causes primary IGF-I resistance despite normal GH and/or IGF-I levels in sera (12-23). Nonetheless, limited information exists on the biological response to IGF-I in vitro in cultured cells and in vivo in patients with mono-allelic expression of the IGF-I receptor $(18,23,24)$.

In this study, we report on a patient with a de novo terminal chromosome deletion, 15q26.1-qter. We show by molecular cytogenetic analysis that the deletion includes the IGF1R gene and provide evidence for reduced IGF-I receptor expression, whereas the basal and IGF-I-regulated levels of IGFBPs were not impaired in the patient's fibroblasts.

\section{Materials and methods}

Sodium $\left[{ }^{125} \mathrm{~T}\right]$ iodine (carrier free; specific activity $16.9 \mathrm{mCi} / \mu \mathrm{g}$ iodine), ${ }^{125}$ I-IGF-I, and prestained protein standard (Rainbow) were purchased from AmershamPharmaciaBiotech (Freiburg, Germany). $\left[\alpha-1-{ }^{14} \mathrm{C}\right]-$ Methylaminoisobutyric acid $\left(\left[\alpha-1-{ }^{14} \mathrm{C}\right] \mathrm{Me}-\mathrm{AiBu}\right)$ and methylaminoisobutyric acid were from Perkin Elmer Life Sciences (Boston, MA, USA), and Sigma-Aldrich (Schnelldorf, Germany) respectively. Recombinant human (rh) IGF-I, IGF-II, des(1-6) IGF-II, and biotinylated IGF-II were from GroPep (Adelaide, Australia). Nonglycosylated rhIGFBP-3 was a generous gift from Dr A Sommer and Dr C Maack (Celtrix, Santa Clara, CA, USA). IGFBP-3 was iodinated using IODO-GEN (Pierce Chemical, Rockford, IL, USA) as described (25). Antibodies directed against the human IGF-I receptor (Ab-1) were from Oncogene (Boston, MA, USA). Peroxidase-conjugated goat anti-rabbit IgG, fluorescein isothiocyanate (FITC)-labeled avidin, and FITC-conjugated goat-anti-avidin antibodies came from Dianova (Hamburg, Germany). Disuccinimidyl suberate (DSS) was purchased from Pierce.

\section{Subject}

The patient is the first child of non-consanguineous healthy parents. She was born at 39 weeks of gestation with a weight of $2130 \mathrm{~g}$ and length of $45 \mathrm{~cm}$ (both on 3rd percentile). Pregnancy was complicated by placental insufficiency and oligohydramnion. Multiple anomalies were noted at birth such as triangular shaped head, hypertelorism, low-set ears, and higharched palate. Respiratory distress developed soon after birth, intubation and mechanical ventilation were necessary. Additionally, various abnormalities were found such as hypoplastic lungs, dextropositio cordis, atrial septum defect, malrotation of the intestine, skeletal abnormalities of the sacrum (listed in Table 1). At 2 years of age, psychomotor and developmental delay as well as growth failure became apparent and persisted thereafter. At the age of 3.5 years her height standard deviation score (SDS) was - 5.6 and her bone age corresponded to 1.5 years. At present, she is 5 years old (Fig. 1), and her height is SDS -6.5 . At the age of three months the girl underwent operations on her intestine (malrotation operation) and on her diaphragm. Correction of her atrial septum defect was performed three months later. Because of severe feeding difficulties, a percutaneous gastric tube was necessary when she was two years old. She learnt to walk when she was two years old, but she is not able to speak proper words at the age of 5 years.

The study was approved by the Ethics Committee of Hamburg University. Written informed consent was obtained from her parents.

Table 1 Clinical comparison of the present case with other del15q26.1 patients*.

\begin{tabular}{|c|c|c|}
\hline Symptoms/stigmata & $\begin{array}{c}15 q 26.1 \rightarrow \text { qter } \\
\text { present case }\end{array}$ & $\begin{array}{c}\% \text { of total } \\
\quad(n=6)\end{array}$ \\
\hline \multicolumn{3}{|l|}{ Pregnancy } \\
\hline IUGR & + & 100 \\
\hline Oligohydramnios & + & 33 \\
\hline \multicolumn{3}{|l|}{ Craniofacial } \\
\hline Hypertelorism & - & 17 \\
\hline High-arched palate & + & 50 \\
\hline Abnormal ears & - & 67 \\
\hline Micrognathia & + & 83 \\
\hline \multicolumn{3}{|l|}{ Cardiopulmonary } \\
\hline Cardiac abnormality & + & 67 \\
\hline Lung hypoplasia & + & 50 \\
\hline Diaphragmatic hernia & - & 17 \\
\hline Relaxation of diaphragm & + & 17 \\
\hline \multicolumn{3}{|l|}{ Renal } \\
\hline Small/hypoplastic kidneys & - & 17 \\
\hline \multicolumn{3}{|l|}{ Skeletal } \\
\hline Clinodactyly & - & 33 \\
\hline $\begin{array}{l}\text { Proximal placement } \\
\text { of thumb and toe }\end{array}$ & + & 33 \\
\hline Feet abnormalities & + & 33 \\
\hline \multicolumn{3}{|l|}{ Neurodevelopment } \\
\hline Developmental delay & + & 83 \\
\hline Failure to thrive & + & 50 \\
\hline Growth failure & + & 67 \\
\hline \multicolumn{3}{|l|}{ Metabolic } \\
\hline Hypoglycemia & - & 17 \\
\hline High $\mathrm{GH}$ level & + & 17 \\
\hline
\end{tabular}

*References 17, 18, 20, 23.

IUGR, intrauterine growth retardation. 


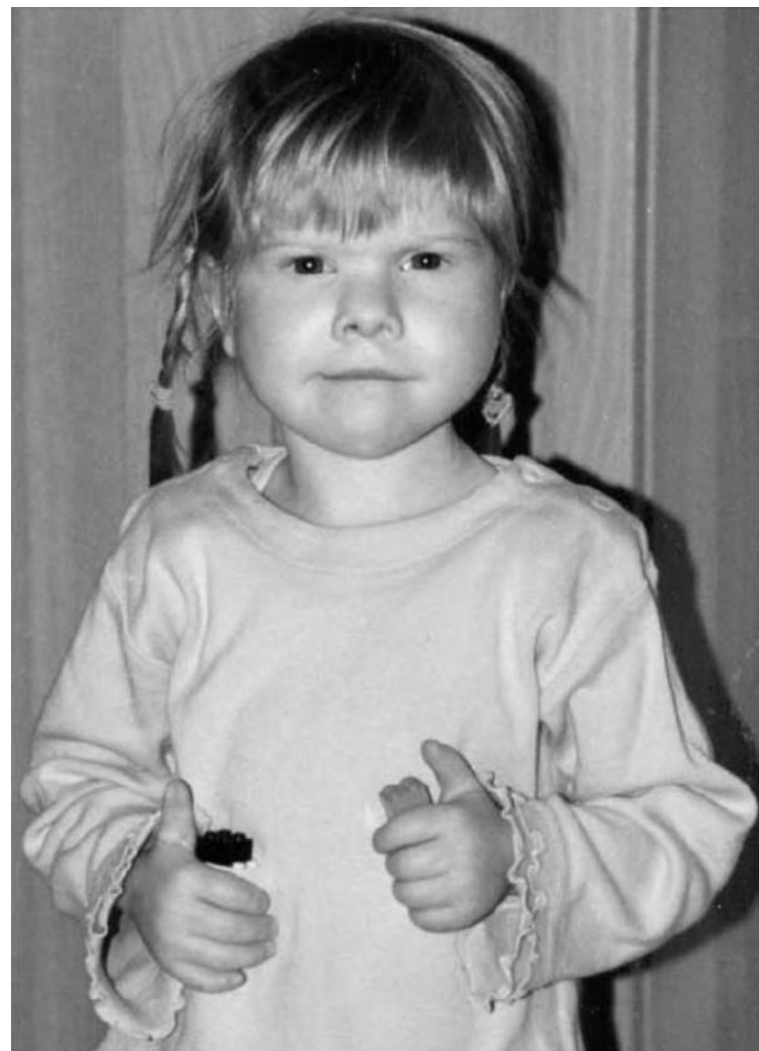

Figure 1 The patient at the age of 5 years.

\section{Hormone assays}

Serum levels of GH, IGF-I, and IGFBP-3 were determined using radioimmunoassay kits (Biochem ImmunoSystems, Freiburg, Germany and Mediagnost, Reutlingen, Germany). For a 3.5-year-old girl, the normal range (5th to 95th percentile) for IGF-I is 39 to $194 \mathrm{ng} / \mathrm{ml}$, and the normal range for IGFBP3 varies from 0.98 to $2.64 \mathrm{mg} / \mathrm{l}$.

\section{Cell culture}

Fibroblasts were obtained by skin biopsy of the patient and from two age-matched controls. If not indicated, in all experiments shown control 1 fibroblasts were used for direct comparison with the patient's fibroblasts. Cells were grown in $35 \mathrm{~mm}$ or 24-well dishes in Dulbecco's modified Eagle's medium (DMEM) containing $10 \%$ fetal bovine serum, streptomycin and penicillin and used for 4-6 passages. Media conditioned for $48-72 \mathrm{~h}$ in the absence or presence of IGF $(100 \mathrm{nmol} / \mathrm{l})$ were prepared as described earlier (26).

\section{Screening of PAC library RPCI1,3-5}

To identify PAC clones containing different parts of the IGF1R gene (GenBank accession no. NM_000875) DNA pools from library RPCI1,3-5 (RPCIP704) were screened by PCR. Libraries and clones were provided by the Resource Center of the German Human Genome Project at the Max-Planck Institute for Molecular Genetics, Berlin, Germany. PAC DNA of positive clones (I16361 and B07439) was prepared using the JETSTAR Plasmid Midiprep kit (Genomed, Löhne, Germany). The IGF1R1F (5'-TCCGCAACGACTATCAGCAGCTG-3') and IGF1R1R (5'-GTAGTTGTACTCATTGTTGATGG- $3^{\prime}$ ) primers were mixed to amplify the $5^{\prime}$ part of the IGF1R gene resulting in a PCR product of $493 \mathrm{bp}$ on genomic DNA and on pools with PACs containing this DNA region. PCR cycling was carried out on an MJ Research PTC-200 thermal cycler (Biozym, Hessisch Oldendorf, Germany) using initial denaturation at $94^{\circ} \mathrm{C}$ for $4 \mathrm{~min}, 3$ cycles at $94^{\circ} \mathrm{C}$ for $30 \mathrm{~s}, 58^{\circ} \mathrm{C}$ for $10 \mathrm{~s}, 72^{\circ} \mathrm{C}$ for $1 \mathrm{~min}, 3 \mathrm{cycles}$ at $94^{\circ} \mathrm{C}$ for $30 \mathrm{~s}, 56^{\circ} \mathrm{C}$ for $10 \mathrm{~s}, 72^{\circ} \mathrm{C}$ for $1 \mathrm{~min}$, and 30 cycles at $94^{\circ} \mathrm{C}$ for $30 \mathrm{~s}, 54^{\circ} \mathrm{C}$ for $10 \mathrm{~s}, 72^{\circ} \mathrm{C}$ for $1 \mathrm{~min}$. Final extension was at $72^{\circ} \mathrm{C}$ for $10 \mathrm{~min}$. Amplification of the $3^{\prime}$ part of the IGF1R gene was carried out with primers IGF1R3F (5'-ACAAAGGGCCATCGTTCATCCAAG-3') and IGF1R3R (5'-ATGGAGCAACCAGCTGCCATGCTC$\left.3^{\prime}\right)$. A 143-bp product was generated on genomic DNA and on pools with PACs containing this DNA region. PCR cycling was carried out on an MJ Research PTC-200 thermal cycler using initial denaturation at $94^{\circ} \mathrm{C}$ for $4 \mathrm{~min}, 3$ cycles at $94^{\circ} \mathrm{C}$ for $30 \mathrm{~s}, 60^{\circ} \mathrm{C}$ for $10 \mathrm{~s}, 72^{\circ} \mathrm{C}$ for $20 \mathrm{~s}, 3$ cycles at $94^{\circ} \mathrm{C}$ for $30 \mathrm{~s}, 58^{\circ} \mathrm{C}$ for $10 \mathrm{~s}, 72^{\circ} \mathrm{C}$ for $20 \mathrm{~s}$, and 30 cycles at $94^{\circ} \mathrm{C}$ for $30 \mathrm{~s}, 56^{\circ} \mathrm{C}$ for $10 \mathrm{~s}, 72^{\circ} \mathrm{C}$ for $20 \mathrm{~s}$. Final extension was at $72^{\circ} \mathrm{C}$ for $10 \mathrm{~min}$.

\section{Cytogenetic analysis, labeling of probes, and fluorescence in situ hybridization (FISH)}

Metaphase spreads for GTG-banding were made by standard procedures from peripheral blood lymphocytes and from umbilical cord fibroblasts. To obtain chromosomes suitable for high resolution banding, the lymphocyte culture was incubated with methotrexate $\left(10^{-5} \mathrm{~mol} / \mathrm{l}\right.$ final concentration) prior to harvesting. Cell division was blocked at prometaphase by adding colcemid $(0.1 \mu \mathrm{g} / \mathrm{ml}$; GIBCO Invitrogen, Karlsruhe, Germany) for the last $20 \mathrm{~min}$. For FISH-analysis $1 \mu \mathrm{g}$ PAC DNA was labeled in a $50 \mu \mathrm{l}$ reaction volume with biotin-14-dATP using the BIONICK labeling system according to the manufacturer's instructions (GIBCO Invitrogen). Prehybridization of the labeled probe with $\mathrm{C}_{\mathrm{o}} \mathrm{t}$ 1-DNA and hybridization reactions (200 ng labeled probe per slide with lymphocyte metaphases) were carried out according to standard protocols. FITC-labeled avidin (1:200) and FITC-conjugated anti-avidin antibodies (Vector/Alexis, Grünberg, Germany) were used for detection and amplification of signals. Chromosomes were counterstained with propidium iodide. Slides were analyzed under a Zeiss Axiophot epifluorescence microscope (Zeiss, Jena, Germany) using a $\times 63$ oil immersion lens. 


\section{IGF-I cross-linking}

Fibroblasts were incubated with DMEM containing $0.1 \%$ BSA for $1 \mathrm{~h}$ followed by three washes with icecold phosphate-buffered saline (PBS). The cells were incubated for $12 \mathrm{~h}$ at $4{ }^{\circ} \mathrm{C}$ with ${ }^{125} \mathrm{I}$-IGF-I (800000 c.p.m./dish) in the presence or absence of unlabeled IGF-I $(200 \mathrm{nmol} / \mathrm{l})$. After cross-linkage using freshly prepared DSS $(0.2 \mathrm{mmol} / \mathrm{l})$, the labeled proteins were analyzed by SDS-PAGE $(8 \%$ polyacrylamide) under reducing conditions and visualized by autoradiography as described previously (27).

\section{Western-ligand blot}

Conditioned media were adjusted to $70 \%$ ethanol and incubated for $5 \mathrm{~h}$ at $-20^{\circ} \mathrm{C}$. After centrifugation, the precipitated proteins were solubilized and processed for ligand blotting using mono-biotinylated IGF-II as described previously (28).

\section{FACS analysis}

Trypsinized fibroblasts from the patient and control persons were treated with trypsin inhibitor, and washed three times with PBS at room temperature. Then cells were incubated with $1 \mu \mathrm{g} / \mathrm{ml}$ mouse IGF-I receptor antibody or an isotype control for $90 \mathrm{~min}$ at $4^{\circ} \mathrm{C}$, washed and incubated with phycoerythrin-conjugated anti-mouse Ig (Dianova) for $1 \mathrm{~h}$ at $4{ }^{\circ} \mathrm{C}$. After washing three times with PBS, cells were fixed in 3\% paraformaldehyde followed by incubation with $50 \mathrm{mmol} / \mathrm{l}$ ammonium chloride for 10 min before FACS analysis.

\section{$\left[\alpha-1-{ }^{14} \mathrm{C}\right] \mathrm{Me}-\mathrm{AiBu}$ transport}

IGF-I-stimulated $\left[\alpha-1-{ }^{14} \mathrm{C}\right] \mathrm{Me}-\mathrm{AiBu}$ transport was measured as described using the cluster tray method (18) with modifications. Eight days after plating, cells were washed with Hank's balanced salt solution supplemented with $0.7 \mathrm{~g} / 500 \mathrm{ml} \mathrm{NaHCO}_{3}(\mathrm{HBSS}+)$ and incubated with HBSS + containing $0.1 \%$ bovine serum albumin (BSA). After $24 \mathrm{~h}$ of conditioning, the cells were incubated for a further $3 \mathrm{~h}$ in the same medium in the presence or absence of $50 \mathrm{nmol} / \mathrm{l} \mathrm{IGF-I}$ followed by the addition of $\left[\alpha-1-{ }^{14} \mathrm{C}\right] \mathrm{Me}-\mathrm{AiBu}$ $(1 \mu \mathrm{Ci} / \mathrm{ml}, 30 \mu \mathrm{mol} / \mathrm{l} \mathrm{Me}-\mathrm{AiBu})$ in HBSS $+0.1 \% \mathrm{BSA}$. The 24 -well dish was incubated for $20 \mathrm{~min}$ at $37^{\circ} \mathrm{C}$ and processed as described (18).

\section{Results}

\section{Cytogenetic analysis}

G-banding of chromosomes revealed loss of the terminal long arm fragment of one chromosome 15 in all metaphases from lymphocytes $(n=20)$ and from fibroblasts $(n=15)$ of the patient. The breakpoint point was assigned to $15 \mathrm{q} 26.1$ based on the high resolution GTGbanding pattern (Fig. 2A). Subsequent analysis of parental chromosomes yielded normal karyotypes for the patient's mother and father. Thus, the patient carries a de novo terminal deletion of the long arm of chromosome 15 with karyotype $46, X X, \operatorname{del}(15)(q 26.1)$. In order to analyze whether the terminal deletion includes the

\section{A}

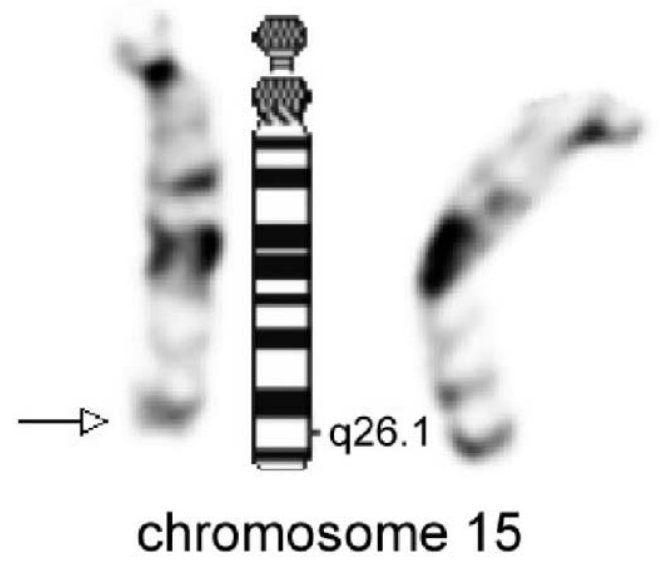

B

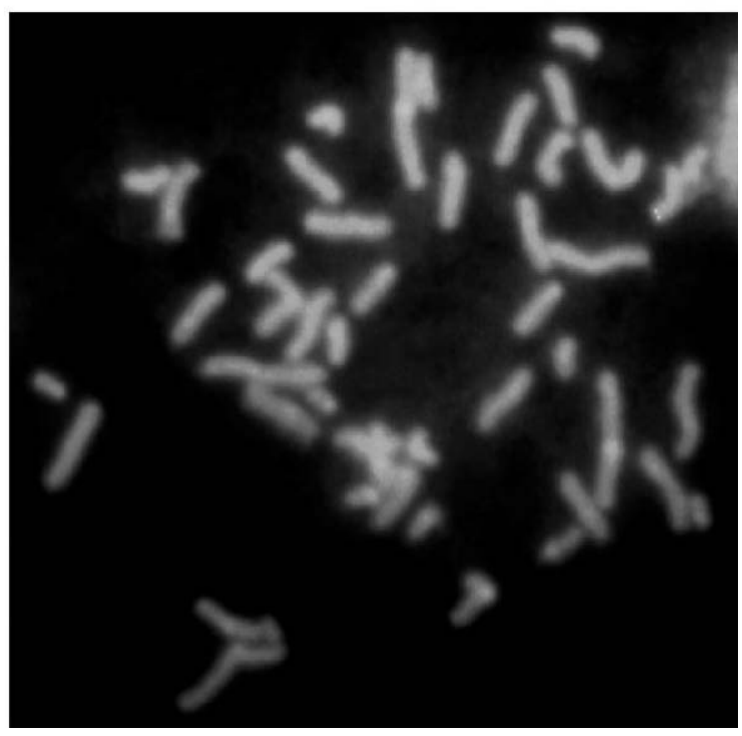

Figure 2 Mono-allelic loss of the terminal long arm of chromosome 15. (A) High resolution of the GTG-banded chromosome 15 pair (approximately 500 bands per haploid set, ISCN 1995) from the patient revealed a deletion of the terminal long arm fragment of one of the two homologs of chromosome 15. The breakpoint region is indicated by an arrow resulting in an unbalanced karyotype 46,XX,del(15)(q26.1). (B) Hybridization of FITC-labeled PAC I16361 (containing the $5^{\prime}$ end of the IGF1R gene) on lymphocyte metaphase spreads from the patient. Chromosomes are counterstained with propidium iodide. There is only one hybridization signal that is found in the expected position near the long arm telomer of a group $\mathrm{D}$ chromosome. The second hybridization signal is missing, indicating a deletion of the IGF1R gene on one chromosome 15. 


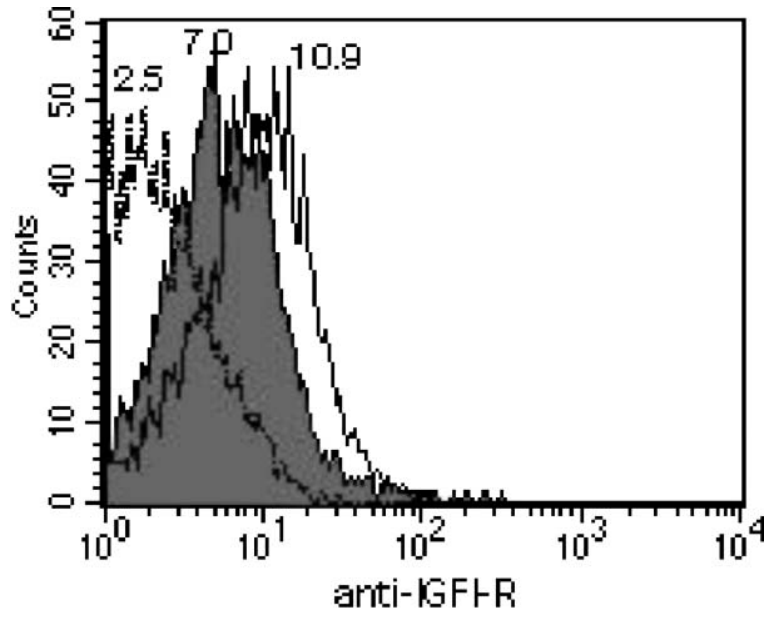

Figure 3 Flow cytometric analysis of IGF-I receptor localized at the cell surface. Suspended fibroblasts from control (open histogram) and the patient (shaded histogram) were incubated for $90 \mathrm{~min}$ at $4^{\circ} \mathrm{C}$ with the monoclonal antibody $\mathrm{Ab}-1$ against the human IGF-I receptor. After washing, the cells were further incubated with PE-conjugated anti-mouse Ig and analyzed by flow cytometry. The histogram with the dotted line represents normal fibroblasts incubated with an irrelevant isotype control antibody. Numbers above the histograms represent the mean fluorescence intensities.

IGF1R gene, FISH studies were carried out with two PAC clones, I16361 and B07439, containing either the $5^{\prime}$ or the $3^{\prime}$ region of the IGF1R gene. For each clone 20 hybridized metaphases were analyzed. We obtained a single hybridization signal near the tip of the long arm of a group D chromosome for both PAC clones (Fig. 2B, and data not shown) indicating that the complete IGF1R gene is deleted on the structurally aberrant chromosome 15. Therefore, the karyotype is 46,XX, del(15)(q26.1). ish $\operatorname{del}(15)(\mathrm{q} 26.3)(\mathrm{IGF} 1 \mathrm{R}-)_{\text {de novo }}$.

\section{IGF-I receptor expression in fibroblasts}

To quantitate IGF-I receptors at the cell surface, suspended fibroblasts were incubated with monoclonal antibodies against the IGF-I receptor and monitored by flow cytometry. About twofold higher staining intensity was detected in control cells (Fig. 3, open histogram) compared with the patient's cells (shaded histogram). Affinity cross-linking of ${ }^{125}$ I-labeled IGF-I showed the labeling of a $135 \mathrm{kDa}$ band representing the $\alpha$-subunit of the IGF-I receptor in both control and patient cells. The binding was specific and could be abolished in the presence of an excess of unlabeled IGF-I. Densitometric evaluation revealed that in the patient's cells the amount of cross-linked products was $43 \%$ of control cells (Fig. 4).

\section{IGFBP expression and response to IGF}

There was no significant elevation in IGF-I levels in the plasma (125 $\mu \mathrm{g} / \mathrm{l}$ corresponding to the 80 th percentile).

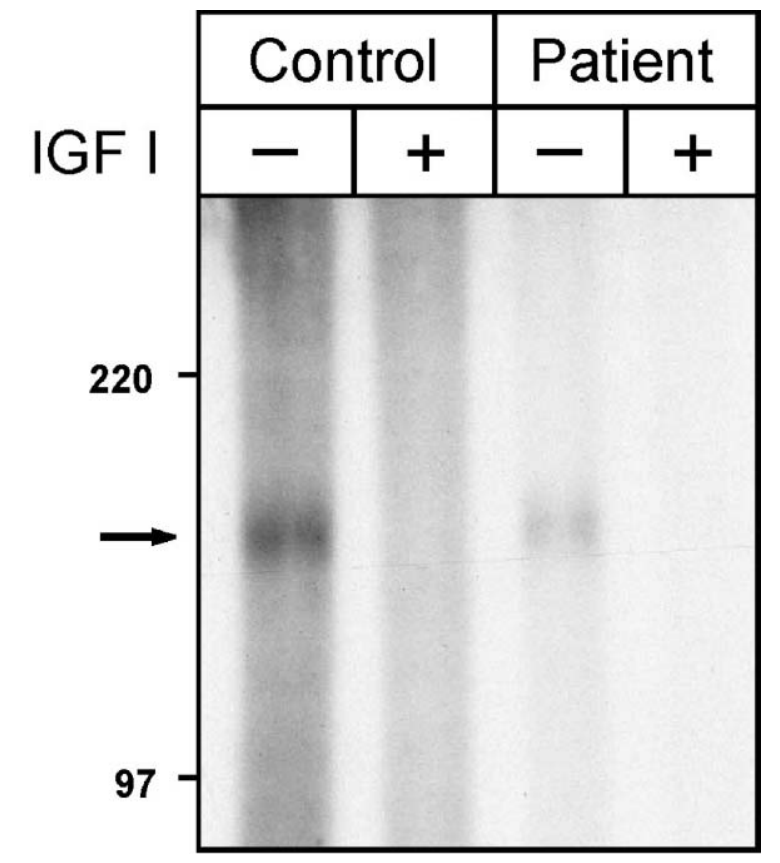

Figure 4 Affinity cross-linking of ${ }^{125}$ I-IGF-I to cell surface receptors. Fibroblasts were incubated with ${ }^{125}$ I-IGF-I in the absence $(-)$ or presence $(+)$ of unlabeled IGF-I $(200 \mathrm{nmol} / \mathrm{I})$ at $4{ }^{\circ} \mathrm{C}$. IGF-I receptor-ligand complexes were cross-linked with DSS and separated by SDS-PAGE under reducing conditions. An autoradiogram of a representative experiment is shown. The position of the IGF-I receptor (arrow), and molecular mass markers $(\mathrm{kDa})$ are indicated.

The GH and IGFBP-3 levels were also in the upper normal range $(20.3 \mu \mathrm{g} / \mathrm{l}$ corresponding to $>95$ th percentile, and $3.4 \mathrm{mg} / \mathrm{l}$ corresponding to $>95$ th percentile respectively). The latter was confirmed by IGF ligand blotting of serum samples showing similar

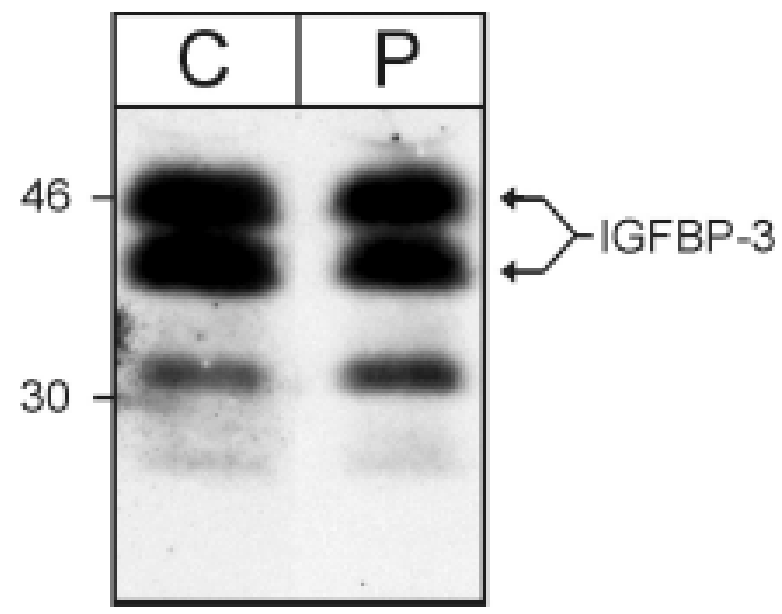

Figure 5 Ligand blot analysis. Serum samples $(1 \mu \mathrm{l})$ of the patient (P) and an age-matched control (C) were separated by SDSPAGE under non-reducing conditions, transferred to nitrocellulose membranes and tested by ligand blotting using biotinylated IGF-II, followed by ECL. The position of the $43 / 45 \mathrm{kDa}$ IGFBP-3 doublet is indicated. 

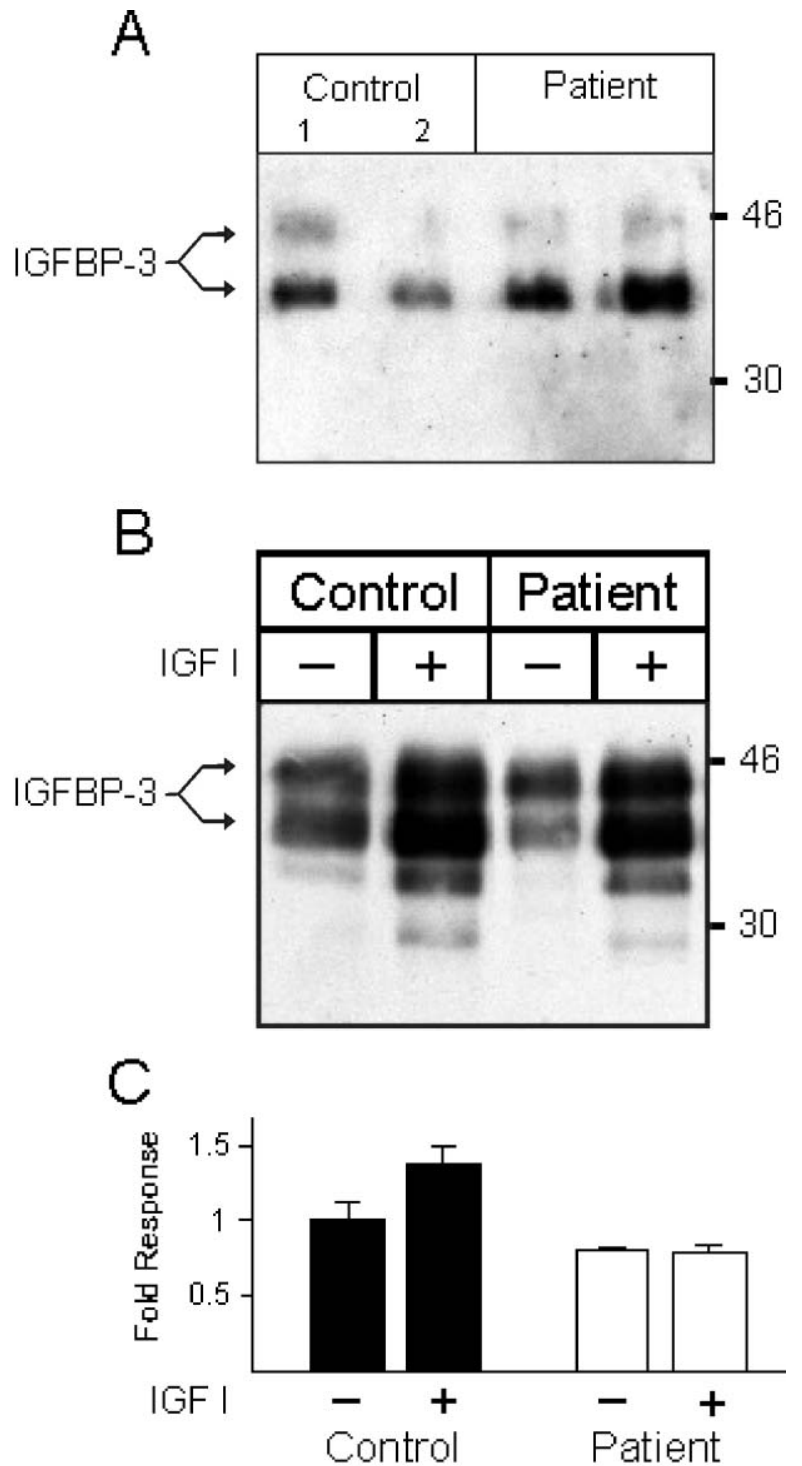

Figure 6 Biological response to IGF-I. (A) Fibroblasts from two controls ( 1 and 2 ) and two patient cultures were incubated in serum-free medium for $24 \mathrm{~h}$. Aliquots $(0.3 \mathrm{ml})$ were analyzed by IGF-II-ligand blotting. The positions of the IGFBP-3 doublet and of molecular mass marker proteins are indicated. (B) Control and patient's fibroblasts were incubated in serum-free medium in the presence $(+)$ or absence $(-)$ of IGF-I for $48 \mathrm{~h}$ and analyzed by ligand blotting. The position of the IGFBP-3 doublet is indicated. (C) $\left[\alpha-1-{ }^{14} \mathrm{C}\right] \mathrm{Me}$-AiBu transport experiments in the presence or absence of $50 \mathrm{nmol} / \mathrm{I}$ IGF-I were performed as described in Materials and methods. The internalized radioactivity in control cells (solid bars) and the patient's fibroblasts (open bars) was determined and expressed as the fold response over basal uptake in non IGF-I-treated control cells. The results were pooled from two separate experiments carried out in triplicate. The uptake of Me-AiBu was calculated to be $89 \pm 6 \mathrm{pmoles} / 20 \mathrm{~min} /$ well.

amounts of both the 43/45 kDa IGFBP-3 doublet as well as of other binding proteins (Fig. 5).

When conditioned media from control 1, control 2 and the patient's fibroblasts were analyzed by IGF ligand blotting, the $43 / 45 \mathrm{kDa}$ IGFBP-3 doublet represented the most prominent binding protein in both media (Fig. 6A). The basal amounts of IGFBP-3 secreted from the patient's fibroblasts were similar or up to twofold higher than those from control 1 or control 2 cells respectively (Fig. 6A). Two other IGFBPs with apparent molecular masses of 35 and $30 \mathrm{kDa}$, as well as a very weak $25 \mathrm{kDa}$ band, were also visible after longer exposure (Fig. 6B). Treatment of the control 1 fibroblasts with $100 \mathrm{nmol} / \mathrm{l}$ IGF-I for $48 \mathrm{~h}$ increased the abundance of all IGFBPs about 1.7-fold, as estimated by densitometric evaluation (Fig. 6B). The same responses were observed with IGF-II or IGF analogs, des(1-3) IGF-I and des(1-6) IGF-II (not shown), exhibiting reduced affinities for IGFBPs (29, 30). In the patient's fibroblasts the extent of IGF-Istimulated abundance of IGFBPs in the media appeared to be slightly increased (2- to 2.8-fold) (Fig. 6). The differences in IGFBP abundance were not due to different IGFBP protease activities in the media of control and patient fibroblasts (data not shown). These data indicate that the abundance of IGFBPs in the medium of patient's cells under basal and IGF-I-stimulated conditions are increased independent of the IGF-I receptor concentration.

To examine the significance of the increased IGFBPs in the media of the patient's fibroblasts, the uptake of the nonmetabolizable amino acid, $\left[\alpha-1-{ }^{14} \mathrm{C}\right] \mathrm{Me}-\mathrm{AiBu}$, was measured in the absence and presence of $50 \mathrm{nmol} / \mathrm{l}$ IGF-I. Therefore, the cells were first conditioned in serum-free buffer solution for $24 \mathrm{~h}$ prior addition of IGF-I and $\left[\alpha-1-{ }^{14} \mathrm{C}\right] \mathrm{Me}-\mathrm{AiBu}$. The basal uptake of $\left[\alpha-1-{ }^{14} \mathrm{C}\right] \mathrm{Me}-\mathrm{AiBu}$ was slightly higher in the control than in the patient's fibroblasts (Fig. 6C).

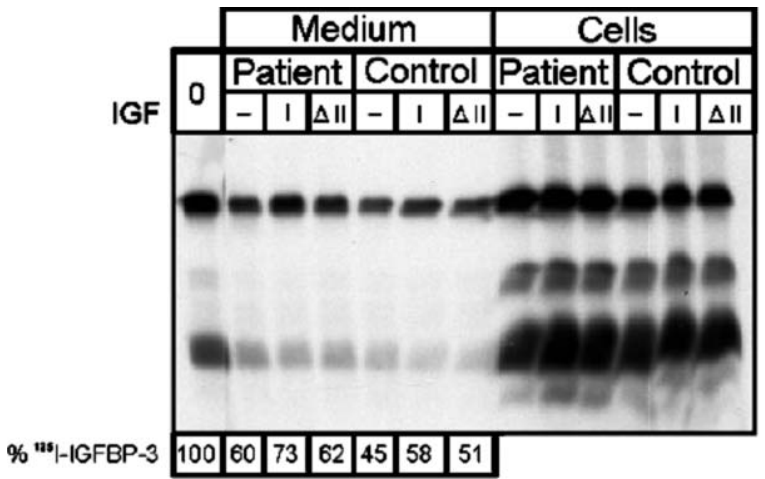

Figure 7 Cell-dependent degradation of IGFBP-3. Control and patient fibroblasts were incubated for $3 \mathrm{~h}$ with ${ }^{125}$ I-labeled IGFBP3 (250000 c.p.m./plate) in serum-free medium in the presence or absence $(-)$ of $100 \mathrm{nmol} / \mathrm{I} \mathrm{IGF-I} \mathrm{(I)}$ or des(1-6) IGF-II $(\Delta \mathrm{II})$. After removal of the medium, the washed cells were scraped and collected by centrifugation. Aliquots of the medium (15\% of total) and the cells were solubilized and analyzed by SDS-PAGE and autoradiography. An aliquot of ${ }^{125}$-labeled IGFBP-3-containing medium incubated in the absence of cells was used as control (0). The visualized IGFBP-3 bands in the medium were quantified by densitometric scanning. The value obtained for IGFBP-3 in the control (0) medium was set to $100 \%$. The experiment was repeated twice. 
In response to IGF-I, control cells showed a 1.4-fold increase over basal $\left[\alpha-1-{ }^{14} \mathrm{C}\right] \mathrm{Me}-\mathrm{AiBu}$ uptake under these conditions whereas the patient's fibroblasts failed to respond to IGF-I (Fig. 6C).

It has been suggested that IGFBP-3 can bind via IGFs to the IGF-I receptor localized at the cell surface (31). Additionally, resistance to IGF-I has been reported in fibroblasts from a child with short stature caused by an abnormal cell association of IGFBPs (32). To examine whether the reduced number of IGF-I receptors in the patient's fibroblasts affects the binding and degradation of IGFBP-3, fibroblasts were incubated with the $30 \mathrm{kDa}$ non-glycosylated recombinant ${ }^{125}$ I-IGFBP-3 for $14 \mathrm{~h}$ at $37^{\circ} \mathrm{C}$ in the presence and absence of IGF-I or des(1-6) IGF-II. The amounts of cell-associated intact IGFBP-3 and their 25 and $14 \mathrm{kDa}$ fragments were similar in fibroblasts from the control and the patient's fibroblasts and neither was affected by IGF-I or by des(1-6) IGF-II (Fig. 7; right side). Analysis of the ${ }^{125}$ I-IGFBP-3 remaining in the medium after the incubation period revealed higher amounts of intact IGFBP-3 in the medium of the patient's fibroblasts (60\% vs 45\%; Fig. 7; left side, lanes 2 and 5). These differences persist also in the presence of IGF-I or des(1-6) IGF-II. In these medium samples less IGFBP3 degradation products $(6-12 \%)$ were detected, measured as trichloroacetic acid soluble radioactivity (not shown). The data indicate that IGFBP-3 is degraded by fibroblast cell-associated IGFBP-3 protease(s) which appear to be less efficient in the patient's fibroblasts than in control cells.

\section{Discussion}

Here we report on a short child who carries only one copy of the IGF-I receptor gene (IGF1R) due to a deletion of the terminal $15 \mathrm{q}$ segment. The mono-allelic expression of IGF1R was confirmed by FISH analysis. These findings suggest that the mono-allelic loss of the IGF-I receptor may be causative for the severe growth deficiency seen in the patient. There are only 12 cases documented with a mono-allelic loss of the IGF1R gene in children with deletions of the distal long arm of chromosome 15. The clinical findings of the patient presented in this work in comparison with those five patients showing a 15q26.1-qter (17, 18, $20,23)$ indicate that intrauterine growth retardation (IUGR), high-arched palate, abnormal ears, micrognathia, cardiac abnormality, lung hypoplasia, developmental delay, and postnatal growth failure are the major signs and symptoms present in these children (observed in at least $50 \%$ of the patients; Table 1 ). Since heterozygous Igf $1 r$ knockout mice did not show any discernible phenotype (7) it can be speculated that mono-allelic loss of genes located distally from the IGF1R may contribute to the severe disease phenotype of the patients. The heterogeneity in the expression of the symptoms of the other seven described patients with mono-allelic IGF-I receptor expression cannot be compared directly due to the distinct sites of chromosomal breakage resulting in terminal deletions of distal $15 \mathrm{q}$ such as del 15q21 (13), 15q22-q24 (14), 15q24 (15), or $15 q 26.2$ (23). Thus, in addition to IGF1R, loss of other genes may contribute to the variations in expressivity, manifested as variable phenotypic features. Among those genes mapped distally of the IGF1R gene, furin (15q26.1) and ADAMTS17 (15q26.3) may play a role in growth regulation. Furin is involved in the endoproteolytic processing of the IGF-I receptor that is crucial for its ligand binding and signaling activities (33). Homozygous furin-deficient mice die between embryonic day 10.5 and 11.5 displaying multiple tissue abnormalities such as cardiac insufficiency and shortening of the anteroposterior body axis, whereas heterozygous embryos appear normal (34). ADAMTS17 encodes a disintegrin-like and metalloprotease-withthrombospondin type 1 motif of unknown function and substrate specificity (35). However, other members of the ADAM family of proteases have been identified as IGFBP-3 and -5 proteases $(36,37)$. It is likely that mono-allelic losses of multiple genes regulating, for example, the expression of different components of the IGF axis act in an additive manner and impair pre- and postnatal growth.

There are only two studies that investigated expression of the IGF-I receptor and the biological response to IGF-I in fibroblasts from patients with mono-allelic loss of the IGF-I receptor gene $(18,23)$. Fibroblasts from these patients and of our patient share the reduced number of IGF-I receptors (to 50\% of controls as shown by ligand binding), IGF-I crosslinking and FACS analysis (18, 23, Figs 3 and 4). However, while the receptor number primarily affects the maximal response to IGF-I $\left({ }^{3} \mathrm{H}\right.$-thymidine incorporation and ${ }^{14} \mathrm{C}$-methylaminoisobutyric acid transport) in one of two patients, the net stimulation (maximal response minus basal) was not decreased at all (18). These data are in agreement with our findings that the IGF-Istimulated increase in the secretion of several IGFBPs was not impaired in fibroblasts of our patient (Fig. 6). In summary, the quantitative deficiency of the IGF-I receptor due to mono-allelic loss of IGF1R did not lead to the expected IGF-I resistance in fibroblasts. However, the expression of the IGF-I receptor in tissues other than fibroblasts and the interaction with other local components of the IGF axis, such as IGFBPs and IGFBP proteases, might show a different IGF-I-dependent growth response.

Resistance to IGF-I in vivo has been observed in a severely growth retarded child with ring chromosome 15 and a mono-allelic deletion of the IGF-I receptor gene treated with recombinant IGF-I for a short period (24). Nonetheless, the molecular mechanisms impairing IGF-I receptor functions in other patients with mono-allelic loss of IGF1R are, as yet, unknown. 
One possible explanation could be that the expression of IGFBPs is altered resulting in growth inhibition by sequestration of IGFs. Indeed, high circulating levels of IGFBP-1 have been found in a child with severe growth failure from birth (38). In addition, the administration of recombinant IGFBP-1 to both hypophysectomized rats as well as IGFBP-1 transgenic mice show impaired fetal and postnatal growth and brain development $(39,40)$. However, the IGFBP-3 level in cord blood (22) and in serum (this study) of patients with a terminal deletion of the long arm of chromosome 15 did not significantly differ from normal controls and the IGFBP pattern in the serum of our patient was also unchanged. However, the abundance of IGFBPs including IGFBP-3 in the medium of the patient's fibroblasts was higher than in control cells which might be due to a less efficient degradation of IGFBP-3 by cell-associated IGFBP-3 protease(s) compared with control cells (Fig. 7). This might lead to a reduced bioavailability of IGFs due to an increased number of IGF-IGFBP-3 complexes as shown by the failure of IGF-I to stimulate the transport of the nonmetabolizable amino acid $\left[\alpha-1-{ }^{14} \mathrm{C}\right]$ methylaminoisobutyric acid. Thus, the possibility that altered IGFBP expression in tissues of patients with a heterozygous deletion of the distal long arm of chromosome 15 contributed to local growth inhibition and impairment of organ development and differentiation, cannot be ruled out.

\section{Acknowledgements}

We thank Raoul Heller for excellent help in the cytogenetic analysis, and Karin Ziegler, Inka Jantke, and Barbara Schröder for skilful technical assistance. This work was supported by a grant from the Deutsche Forschungsgemeinschaft (GRK336).

\section{References}

1 Kant SG, Wit JM \& Breuning MH. Genetic analysis of short stature. Hormone Research 200360 157-165.

2 Le Roith D, Bondy C, Yakar S, Liu JL \& Butler A. The somatomedin hypothesis: 2001. Endocrine Reviews 2001 53-74.

3 Jones JI \& Clemmons DR. Insulin-like growth factors and their binding proteins: biological actions. Endocrine Reviews 199516 3-34.

4 LeRoith D, Werner H, Beitner-Johnson D \& Roberts CT Jr. Molecular and cellular aspects of the insulin-like growth factor I receptor. Endocrine Reviews $199516143-163$.

5 Maile LA \& Holly JM. Insulin-like growth factor binding protein (IGFBP) proteolysis: occurrence, identification, role and regulation. Growth Hormone and IGF Research 1999 9 85-95.

6 Firth SM \& Baxter RC. Cellular actions of the insulin-like growth factor binding proteins. Endocrine Reviews 200223 824-854.

7 Liu JP, Baker J, Perkins AS, Robertson EJ \& Efstratiadis A. Mice carrying null mutations of the genes encoding insulin-like growth factor I (Igf1) and type 1 IGF receptor (Igf1r). Cell 199375 $59-72$.
8 DeChiara TM, Efstratiadis A \& Robertson EJ. A growth-deficiency phenotype in heterozygous mice carrying an insulin-like growth factor II gene disrupted by targeting. Nature $1990 \mathbf{3 4 5} 78-80$.

9 Powell-Braxton L, Hollingshead P. Warburton C, Dowd M, PittsMeek S, Dalton D, Gillett N \& Stewart TA. IGF-I is required for normal embryonic growth in mice. Genes and Development 1993 $72609-2617$.

10 Woods KA, Camacho-Hubner C, Savage MO \& Clark AJ. Intrauterine growth retardation and postnatal growth failure associated with deletion of the insulin-like growth factor I gene. New England Journal of Medicine 1996335 1363-1367.

11 Abuzzahab MJ, Schneider A, Goddard A, Grigorescu F, Lautier C, Keller E, Kiess W, Klammt J, Kratzsch J, Osgood D, Pfaffle R, Raile K, Seidel B, Smith RJ \& Chernausek SD. IGF-I receptor mutations resulting in intrauterine and postnatal growth retardation. New England Journal of Medicine $20033492211-2222$.

12 Pasquali F, Zuffardi O, Severi F, Colombo A \& Burgio GR. Tandem translocation 15-13. Annales de Génétique 197316 47-50.

13 Fryns JP, de Muelenaere A \& van den Berghe H. Interstitial deletion of the long arm of chromosome 15. Annales de Génétique $19822559-60$.

14 Clark RD. Del(15)(q22q24) syndrome with potter sequence. American Journal of Medical Genetics 198419 703-705.

15 Kristoffersson U, Heim S, Mandahl N, Sundkvist L, Szelest J \& Hagerstrand I. Monosomy and trisomy of $15 \mathrm{q} 24--$ qter in a family with a translocation $\mathrm{t}(6 ; 15)(\mathrm{p} 25 ; \mathrm{q} 24)$. Clinical Genetics $198732169-171$

16 Formiga LD, Poenaru L, Couronne F, Flori E, Eibel JL, Deminatti MM, Savary JB, Lai JL, Gilgenkrantz S \& Pierson M. Interstitial deletion of chromosome 15: two cases. Human Genetics $1988 \mathbf{8 0} 401-404$

17 Roback EW, Barakat AJ, Dev VG, Mbikay M, Chretien M \& Butler MG. An infant with deletion of the distal long arm of chromosome 15 (q26.1--qter) and loss of insulin-like growth factor 1 receptor gene. American Journal of Medical Genetics $19913874-79$.

18 Siebler T, Lopaczynski W, Terry CL, Casella SJ, Munson P, De Leon DD, Phang L, Blakemore KJ, McEvoy RC, Kelley RI \& Nissley P. Insulin-like growth factor I receptor expression and function in fibroblasts from two patients with deletion of the distal long arm of chromosome 15. Journal of Clinical Endocrinology and Metabolism $1995 \mathbf{8 0} 3447-3457$.

19 Rogan PK, Seip JR, Driscoll DJ, Papenhausen PR, Johnson VP, Raskin S, Woodward AL \& Butler MG. Distinct 15q genotypes in Russell-Silver and ring 15 syndromes. American Journal of Medical Genetics $1996 \mathbf{6 2} 10-15$.

20 Tönnies H, Schulze I, Hennies H, Neumann LM, Keitzer R \& Neitzel H. De novo terminal deletion of chromosome 15q26.1 characterised by comparative genomic hybridisation and FISH with locus specific probes. Journal of Medical Genetics 200138 617-621.

21 Nagai T, Shimokawa O, Harada N, Sakazume S, Ohashi H, Matsumoto N, Obata K, Yoshino A, Murakami N, Murai T, Sakuta R \& Niikawa N. Postnatal overgrowth by $15 \mathrm{q}$-trisomy and intrauterine growth retardation by $15 \mathrm{q}$-monosomy due to familial translocation $\mathrm{t}(13 ; 15)$ : dosage effect of IGF1R? American Journal of Medical Genetics 2002113 173-177.

22 Fukushima K, Komatsu H, Matsumoto M, Kobayashi H, Tsukimori K, Satoh S \& Nakano H. IGF-related proteins at birth in a case of antenatally diagnosed silver-russell syndrome. Pediatric Research 200251 323-327.

23 Okubo Y, Siddle K, Firth H, O'Rahilly S, Wilson LC, Willatt L, Fukushima T, Takahashi S, Petry CJ, Saukkonen T, Stanhope R \& Dunger DB. Cell proliferation activities on skin fibroblasts from a short child with absence of one copy of the type 1 insulin-like growth factor receptor (IGF1R) gene and a tall child with three copies of the IGF1R gene. Journal of Clinical Endocrinology and Metabolism $2003 \mathbf{8 8} 5981-5988$.

24 de Lacerda L, Carvalho JA, Stannard B, Werner H, Boguszewski MC, Sandrini R, Malozowski SN, Leroith D \& Underwood LE. In 
vitro and in vivo responses to short-term recombinant human insulin-like growth factor-1 (IGF-I) in a severely growth-retarded girl with ring chromosome 15 and deletion of a single allele for the type 1 IGF receptor gene. Clinical Endocrinology 199951 $541-550$.

25 Parker KC \& Strominger JL. Localization of the sites of iodination of human beta 2-microglobulin: quaternary structure implications for histocompatibility antigens. Biochemistry 198322 $1145-1153$.

26 Braulke T, Götz W \& Claussen M. Immunohistochemical localization of insulin-like growth factor binding protein-1, -3 and -4 in human fetal tissues and their analysis in media from fetal tissue explants. Growth Regulation 1996 6 55-65.

27 Körner C, Nürnberg B, Uhde M \& Braulke T. Mannose 6-phosphate/insulin-like growth factor II receptor fails to interact with Gproteins. Analysis of mutant cytoplasmic receptor domains. Journal of Biological Chemistry 1995270 287-295.

28 Kübler B, Draeger C, John H, Andag U, Scharf JG, Forssmann WG, Braulke T \& Ständker L. Isolation and characterization of circulating fragments of the insulin-like growth factor binding protein-3. FEBS Letters $2002 \mathbf{5 1 8} 124-128$.

29 Clemmons D, Dehoff M, Busby W, Bayne M \& Cascieri M. Competition for binding to insulin-like growth factor (IGF) binding protein-2, $-3,-4$, and -5 by the IGFs and IGF analogs. Endocrinology $1992131890-895$

30 Francis G, Aplin S, Milner S, McNeil K, Ballard F \& Wallace J. Insulin-like growth factor (IGF)-II binding to IGF-binding proteins and IGF receptors is modified by deletion of the N-terminal hexapeptide or substitution of arginine for glutamate- 6 in IGF-II. Biochemical Journal 1993293 713-719.

31 Ferry R Jr, Katz L, Grimberg A, Cohen P \& Weinzimer S. Cellular actions of insulin-like growth factor binding proteins. Hormone and Metabolic Research 199931 192-202.

32 Tollefsen S, Heath-Monnig E, Cascieri M, Bayne M \& Daughaday W. Endogenous insulin-like growth factor (IGF) binding proteins cause IGF-I resistance in cultured fibroblasts from a patient with short stature. Journal of Clinical Investigation 199187 1241-1250.

33 Roebroek A, Umans L, Pauli I, Robertson E, van Leuven F, Van de Ven W \& Constam D. Failure of ventral closure and axial rotation in embryos lacking the proprotein convertase furin. Development $19981254863-4876$.

34 Lehmann M, Andre F, Bellan C, Remacle-Bonnet M, Garrouste F, Parat F, Lissitsky J, Marvaldi J \& Pommier G. Deficient processing and activity of type I insulin-like growth factor receptor in the furin-deficient LoVo-C5 cells. Endocrinology $1998 \quad 139$ 3763-3771.

35 Cal S, Obaya AJ, Llamazares M, Garabaya C, Quesada V \& Lopez-Otin C. Cloning, expression analysis, and structural characterization of seven novel human ADAMTSs, a family of metalloproteinases with disintegrin and thrombospondin-1 domains. Gene $2002 \mathbf{2 8 3} 49-62$.

36 Shi Z, Xu F, Loechel F, Wewer UM \& Murphy LJ. ADAM 12, a disintegrin metalloproteinase, interacts with insulin-like growth factor-binding protein-3. Journal of Biological Chemistry 2000 275 18574-18580.

37 Mohan S, Thompson GR, Amaar YG, Hathaway G, Tschesche H \& Baylink DJ. ADAM-9 is an insulin-like growth factor binding protein- 5 protease produced and secreted by human osteoblasts. Biochemistry 200241 15394-15403.

38 Barreca A, Bozzola M, Cesarone A, Steenbergh P, Holthuizen P, Severi F, Giordano G \& Minuto F. Short stature associated with high circulating insulin-like growth factor (IGF)-binding protein-1 and low circulating IGF-II: effect of growth hormone therapy. Journal of Clinical Endocrinology and Metabolism 1998 83 3534-3541.

39 Cox G, McDermott M, Merkel E, Stroh C, Ko S, Squires C, Gleason T \& Russell D. Recombinant human insulin-like growth factor (IGF)-binding protein-1 inhibits somatic growth stimulated by IGF-I and growth hormone in hypophysectomized rats. Endocrinology $19941351913-1920$.

40 Rajkumar K, Barron D, Lewitt M \& Murphy L. Growth retardation and hyperglycemia in insulin-like growth factor binding protein-1 transgenic mice. Endocrinology 1995136 4029-4034.

Received 20 April 2004

Accepted 28 June 2004 